\title{
Profil Kursus Menjahit pada Lembaga Kursus dan Pelatihan (LKP) Ganesha
}

\author{
Eka Prasetyaningsih, Hapsari Kusumarwardani*, Nur Endah Purwaningsih \\ Universitas Negeri Malang, Jl. Semarang No. 5 Malang, Jawa Timur, Indonesia \\ *Penulis korespondensi, Surel: hapsari.kusumawardani.ft@um.ac.id
}

Paper received: 05-01-2021; revised: 18-01-2021; accepted: 30-01-2021

\begin{abstract}
The purpose of this study is to obtain information about the profile of the sewing course program at LKP Ganesha. This research uses descriptive method with a qualitative approach. Data collection techniques are carried out using observation, interviews, and documentation. The results of the study are: 1) the establishment and development of sewing courses in LKP Ganesha has been through administrative and technical licensing processes, there are four levels of sewing courses and the funding for courses are determined by the level 2) personnel management which includes organizational structure accompanied by clear task division, but the academic qualifications for course instructors are not yet in line with standards, 3) course period are done in three months and the learning materials are in accordance with Course Curriculum Level II and III of Fashion Training, LKP Ganesha does not yet have a structured education calendar and the standardized learning time has not yet reached the minimum standard of course time, 4) learning infrastructure for sewing courses provided are in accordance with the standards set out in the Act, while the learning facilities provided do not meet the established standards, 5) LKP Ganesha cooperates with 11 government, 3 schools and 6 fashion industries, collaborative activities carried out are training providence, licensing related to course programs, institutions quality improvements, and labor distribution. This research is expected to be a reference material for readers who have an interest in establishing educational institutions in the field of clothing and can be used as material for the development of course institutions in the future.
\end{abstract}

Keywords: profile, sewing course program, training, Ganesha.

\begin{abstract}
Abstrak
Tujuan dari penelitian ini yaitu untuk mendapatkan informasi mengenai profil program kursus menjahit di LKP Ganesha. Metode penelitian ini adalah deskriptif dengan pendekatan kualitatif. Teknik pengumpulan data dilakukan menggunakan observasi, wawancara serta dokumentasi. Hasil penelitian yaitu: 1) pendirian dan pengembangan program kursus menjahit di LKP Ganesha melalui proses perijinan administratif dan teknis, terdapat empat level kursus menjahit dengan pembiayaan kursus yang disesuaikan dengan level 2) manajemen personalia yang meliputi struktur organisasi disertai dengan pembagian tugas yang jelas, akan tetapi kualifikasi akademik bagi instruktor belum sesuai dengan standar, 3) kegiatan pembelajaran dilakukan dalam tiga bulan dan materi pembelajarannya berpedoman pada Kurikulum Kursus dan Pelatihan Tata Busana jenjang II dan III berbasis KKNI, LKP Ganesha belum memiliki kalender pendidikan yang terstruktur dan standar waktu belajar belum mencapai standar minimal waktu kursus, 4) prasarana pembelajaran kursus menjahit yang tersedia sesuai dengan standar yang diatur dalam UU, sedangkan sarana pembelajaran yang disediakan belum memenuhi standar yang ditetapkan, 5) LKP Ganesha menjalin kerjasama dengan 11 instansi pemerintah, 3 sekolah dan 6 industri busana, kegiatan kerjasama yang dilakukan yaitu pengadaaan pelatihan, perijinan program kursus, peningkatan mutu lembaga, serta penyaluran tenaga kerja. Penelitian ini diharapkan dapat menjadi bahan rujukan bagi pembaca yang memiliki minat untuk mendirikan lembaga pendidikan di bidang busana, serta dapat menjadi bahan untuk pengembangan lembaga kursus di masa yang akan datang.
\end{abstract}

Kata kunci: profil, lembaga kursus menjahit, pelatihan, Ganesha. 


\section{Pendahuluan}

Lembaga Kursus dan Pelatihan (LKP) merupakan lembaga pendidikan jalur non formal untuk masyarakat yang ingin mendapatkan pengetahuan, skill dan kecakapan untuk mendapatkan pekerjaan, mendirikan usaha mandiri atau melanjutkan pendidikan ke jenjang yang lebih tinggi (Undang - Undang Nomor 20 Tahun 2003). Berdasarkan data dari Direktorat Pembinaan Lembaga Kursus dan Pelatihan tahun 2019, di daerah Malang terdapat 11 lembaga penyedia kursus busana yang memiliki ijin penyelenggaraan resmi. Salah satu LKP tersebut adalah LKP Ganesha yang berada di Kepanjen Kabupaten Malang, LKP yang berdiri sejak tahun 1985 ini menyediakan salah satu program kursus bidang tata busana, yaitu kursus menjahit.

LKP Ganesha menjadi lembaga penyedia kursus yang telah memiliki status akreditasi dari Badan Akreditasi Nasional Pendidikan Nonformal. Salah satu kelebihan yang dimiliki oleh LKP Ganesha yaitu menjadi TUK (Tempat Uji Kompetensi) Menjahit Level II dan III KKNI sejak tahun 2015. Ditunjuknya LKP Ganesha menjadi salah satu tempat untuk Ujikom (Uji Kompetensi) menunjukan bahwa LKP Ganesha menjadi salah satu lembaga kursus tata busana yang memiliki standar dan kualitas yang baik. Penelitian ini diharapkan dapat memberikan wawasan bagi pembaca yang membutuhkan informasi mengenai seluk beluk lembaga kursus, menjadi referensi untuk memperoleh informasi mengenai cara pengelolaan dan manajemen lembaga pendidikan non formal, serta dapat menjadi referensi untuk pencarian tempat kerja yang sesuai dengan bidang yang dikuasai.

\subsection{Pengertian Profil}

Menurut Kompri (2015), profil adalah deskripsi atau tampilan yang menunjukkan ciriciri dan karakteristik dari suatu benda. Profil adalah gambaran singkat dari seseorang, lembaga, organisasi ataupun wilayah yang menggambarkan mengenai gambaran, pandangan atau garis besar mengenai seseorang atau kelompok. Pada penelitian ini, profil yang dimaksud yaitu mendeskripsikan mengenai gambaran atau biografi dari suatu lembaga masyarakat yang disebut dengan Lembaga Kursus dan Pelatihan (LKP) Ganesha pada program kursus menjahit.

\subsection{Pendidikan Jalur Nonformal}

Berdasarkan Undang Undang Nomor 20 Tahun 2003 tentang Sistem Pendidikan Nasional, jalur pendidikan di Indonesia terdiri dari tiga jalur yaitu jalur formal (sekolah), nonformal (pendidikan luar sekolah) dan informal. Lembaga Kursus dan Pelatihan termasuk dalam jalur pendidikan nonformal, yaitu jalur pendidikan yang diselenggarakan bagi masyarakat yang memerlukan layanan pendidikan sebagai pengganti, penambah, dan atau pelengkap pendidikan formal untuk mendukung penyelenggaraan pendidikan yang berkualitas. Penyelenggaraan tiga jalur pendidikan tersebut menjadi salah satu cara pemerintah Indonesia dalam mewujudkan upaya pendidikan seumur hidup (long life education) yang merata untuk seluruh masyarakat Indonesia (UU Nomor 20 tahun 2003).

\subsection{Kursus Menjahit}

Program kursus dan pelatihan menjahit merupakan salah satu program pendidikan yang diselenggarakan untuk memberikan pengetahuan dan keterampilan pada masyarakat dalam bidang menjahit busana. Sasaran penyelenggaraan program kursus menjahit yaitu diperuntukkan bagi masyarakat yang berpendidikan rendah sehingga dapat membuka peluang 
untuk membuka usaha mandiri di bidang menjahit agar nantinya dapat digunakan untuk memenuhi tuntutan hidup (Peraturan Presiden Nomor 12 Tahun 2008).

Keterampilan menjahit yang didapat diharapkan mampu menghasilkan SDM yang membantu pengembangan sektor industri kecil menengah (UKM) dan mengurangi angka pengangguran (Buku Diktat Kursus, 2011). Pendidikan kursus menjahit pada umumnya ditekankan pada pelajaran praktek yang meliputi: (Peraturan Presiden Nomor 12 Tahun 2008).

\section{Metode}

Penelitian ini menggunakan metode deskriptif dengan pendekatan kualitatif. Peneliti berperan sebagai instrumen penelitian. Sumber data penelitian diperoleh dari data primer serta data sekunder. Pada penelitian ini, penggalian data dilakukan dengan tiga teknik pengumpulan data, yaitu observasi, wawancara dan dokumentasi. Tahap - tahap penelitian dilakukan melalui empat tahap, yaitu tahap pra penelitian, pelaksanaan penelitian, pengolahan data serta pelaporan hasil penelitian. Analisis data dilakukan sebelum di lapangan dan juga selama di lapangan. Pengecekan keabsahan data dilakukan dengan menguji kredibilitas melalui perpanjangan pengamatan, peningkatan ketekunan serta triangulasi data dengan triangulasi sumber dan teknik.

\section{Hasil dan Pembahasan}

Pendirian LKP Ganesha disesuaikan dengan peraturan dari Direktorat Lembaga Kursus dan Pelatihan yang harus memenuhi syarat administratif dan teknis. Persyaratan administratif yaitu berupa identitas pendiri, susunan organisasi dan pembagian tugas, surat keterangan domisili, dokumen kepemilikan bangunan, keterangan penggunaan tempat selama tiga tahun, data sarana dan prasarana, serta rincian biaya pendidikan, sedangkan syarat teknis yaitu dokumen rencana pengembangan program kursus. Terdapat empat level/jenjang kursus menjahit di LKP Ganesha dimana materi kursus tiap levelnya menyesuaikan dengan kebutuhan kursus serta mengacu pada Standar Kompetensi Lulusan (SKL) Bidang Tata Busana. LKP Ganesha menetapkan biaya kursus sesuai dengan level kursus, biaya level I dan II yaitu Rp.2.500.000, sedangkan level III dan IV Rp.3.500.000. Biaya tersebut digunakan untuk gaji pengelola dan instruktor, biaya peralatan menjahit, serta biaya penggunaan ruang kelas dan mesin. Penetapan level kursus tersebut telah disesuaikan dengan Peraturan Pemerintah Nomor 19 Tahun 2005, dalam peraturan tersebut tertulis bahwa "lembaga kursus memiliki keleluasaan untuk mengembangkan programnya sesuai dengan kebutuhan masyarakat". Pembiayaan kursus menjahit yang diterapkan telah diatur dengan jelas dan transparan, pengaturan anggaran biaya disesuaikan dengan kebutuhan kursus tanpa ada batasan tertentu dari pemerintah.

Struktur organisasi pada LKP Ganesha dan pembagian tugasnya yaitu: a) pimpinan LKP bertugas sebagai pengelola lembaga, b) penasehat yaitu Dinas Pendidikan sebagai pengarah jalannya kegiatan lembaga kursus, c) koordinator tenaga kependidikan bertugas mengarahkan sekretaris dan bendahara, d) koordinator tenaga pendidik bertugas untuk mengarahkan dan mengatur kegiatan instruktor, e) sekretaris bertugas mendokumentasikan kegiatan LKP, f) bendahara bertugas mengatur keuangan LKP, g) maintenance/teknisi bertanggungjawab terhadap peralatan dan mesin jahit, serta h) humas bertugas melakukan publikasi lembaga. Pembentukan struktur organisasi dan pembagian tugas tersebut sesuai dengan Peraturan Menteri Pendidikan Nasional RI Nomor 49 Tahun 2007 yang mengatur tentang Standar 
Pengelolaan Kursus yang berlaku. Pada peraturan tersebut tertulis bahwa "lembaga kursus dan pelatihan minimal terdapat unsur pimpinan, staf serta pelaksana dan disertai dengan wewenang yang jelas". Kualifikasi akademik bagi instruktor (tenaga pendidik) kursus di LKP Ganesha yaitu minimal lulus dari SMA/sederajat, memiliki kemampuan di bidang menjahit busana dan tidak diharuskan untuk memiliki sertifikat kompetensi. Ketentuan dalam perekrutan instruktor menjahit tersebut belum mengikuti peraturan yang ditetapkan dalam Undang - Undang Nomor 20 Tahun 2003 yang mengatur tentang standar pembimbing kursus, karena dalam peraturan tersebut tertulis bahwa "standar kualifikasi akademik minimal S1 atau D3 yang diperoleh dari perguruan tinggi terakreditasi, memiliki sertifikat kompetensi pembimbing pada kursus dan pelatihan, serta pengalaman kerja sebagai instruktur di bidang keahlian pada kursus atau pelatihan yang relevan" (Peraturan Menteri Pendidikan Nasional Nomor 41 Tahun 2009).

Kurikulum pendidikan yang diberlakukan pada program kursus menjahit mengacu pada Kurikulum Kursus dan Pelatihan Tata Busana jenjang II dan III Berbasis KKNI (Kerangka Kualifikasi Nasional Indonesia), sedangkan Standar Kompetensi Lulusan (SKL) yang berlaku mengacu pada Standar Kompetensi Lulusan berbasis KKNI Level II dan III. LKP Ganesha tidak memiliki kalender pendidikan dan kegiatan pembelajaran menjahit dilaksanakan dengan total 108 jam pelajaran (dilakukan selama tiga bulan). Standar waktu tersebut belum sesuai dengan standar waktu minimal yang ditetapkan dalam Peraturan Presiden Nomor 8 Tahun 2012 yang menerangkan bahwa waktu kursus Tata Busana adalah yang harus dilakukan minimal selama 184 jam pelajaran.

Prasarana pendidikan kursus menjahit meliputi lahan dengan luas $120 \mathrm{~m}^{2}$, Jumlah total ruangan yang ada di LKP Ganesha yaitu sebanyak 7 ruangan. Pada lantai pertama terdapat 6 ruangan yaitu ruang administrasi, galeri/showroom, mushola, toilet, ruang baca, dan ruang komputer, sedangkan pada lantai dua digunakan untuk ruang kelas kursus menjahit dengan luas $11 \mathrm{~m}^{2}$. Sarana untuk pembelajaran yaitu 10 mesin jahit industri high speed, 1 mesin bordir, 1 mesin obras besar standar industri, 1 mesin lubang kancing, 20 mesin bordir manual, 3 komputer, 4 laptop, 10 manekin, 2 mesin overdeck, 1 gunting elektrik, 2 mesin obras butterfly, 1 proyektor, 20 mesin jahit portable, 1 mesin neci, 1 (set) mesin bordir komputer. Prasarana pembelajaran kursus menjahit yang ada pada LKP Ganesha telah sesuai dengan standar prasarana kursus menjahit yang diatur dalam Undang - Undang Nomor 127 Tahun 2014. Akan tetapi, sarana pembelajaran yang tersedia belum memenuhi standar yang ditetapkan jika dilihat dari jumlah dan kelengkapan yang tersedia.

Program kursus menjahit LKP Ganesha memiliki 21 mitra kerja yang terdiri dari 11 instansi pemerintah, 3 sekolah dan 7 industri busana. Pengadaan kerjasama dengan lembaga pemerintah dan sekolah bertujuan untuk memberi dukungan berupa perijinan program kursus dan bantuan dana, pemberian dukungan untuk program - program kewirausahaan, akreditasi lembaga, penyelenggaraan diklat, Pelaksanaan Uji Kompetensi (UJIKOM), serta pendampingan dan SDM yang dimiliki oleh program kursus menjahit. LKP Ganesha juga menjalin kerjasama dengan pemilik usaha di bidang industri busana dan Dinas Tenaga Kerja agar dapat memperoleh informasi mengenai lowongan kerja dan kualifikasi tenaga kerja yang dibutuhkan oleh Dunia Usaha dan Industri (DUDI). Pembentukan kerjasama yang dilakukan oleh LKP Ganesha dengan lembaga mitra tersebut mengikuti pola kemitraan lembaga yang diatur dalam Lampiran Peraturan Direktorat Pembinaan Kursus dan Kelembagaan Tahun 2010 tentang Pola Kemitraan Lembaga Kursus dan Pelatihan. Pada peraturan tersebut tertulis 
bahwa tujuan dari pembentukan kerjasama antara lembaga kursus dengan mitra kerjanya yaitu untuk pembinaan dan pendampingan teknis penyelenggaraan kursus, penyaluran tenaga kerja, penjaminan mutu lembaga, pengadaan uji kompetensi serta akreditasi dan penetapan strandar kursus yang sesuai dengan standar pendidikan nasional (Peraturan Direktorat Pembinaan Kursus dan Kelembagaan , 2010).

\section{Simpulan}

Berdasarkan hasil penelitian, dapat disimpulkan bahwa: a) proses pendirian LKP Ganesha melalui persyaratan administratif dan teknis, terdapat empat level kursus menjahit dengan pembiayaan kursus yang disesuaikan dengan level b) manajemen personalia yang meliputi struktur organisasi disertai dengan pembagian tugas yang jelas, akan tetapi kualifikasi akademik bagi instruktor kursus belum sesuai dengan standar yang ditetapkan, 3) kegiatan pembelajaran dilakukan selama tiga bulan dan materi pembelajarannya berpedoman pada Kurikulum Kursus dan Pelatihan Tata Busana jenjang II dan III berbasis KKNI, LKP Ganesha belum memiliki kalender pendidikan yang terstruktur dan standar waktu belajar belum mencapai standar minimal waktu kursus, 4) prasarana pembelajaran kursus menjahit yang tersedia sesuai dengan standar yang diatur dalam Undang-Undang, sedangkan sarana pembelajaran yang disediakan belum memenuhi standar yang ditetapkan, 5) LKP Ganesha menjalin kerjasama dengan 11 instansi pemerintah, 3 sekolah dan 6 industri busana (DU/DI), kegiatan kerjasama yang dilakukan yaitu pengadaaan pelatihan, pengurusan untuk perijinan terkait program kursus, peningkatan mutu lembaga, serta penyaluran tenaga kerja.

\section{Daftar Rujukan}

Direktorat Pembinaan Kursus dan Pelatihan (2019). Apa dan Bagaimana Pembinaan Kursus dan Kelembagaan. Direktorat Jenderal Pendidikan Nonformal dan Informal (Online). (http://kursus.kemdikbud.com), diakses 16 Juli 2019.

Direktorat Pembinaan Kursus dan Pelatihan (2019). Bimbingan Teknis Peningkatan Mutu Manajemen LKP. Kemdikbud (Online). (Http:// kursus.kemdikbud.com), diakses 17 Juli 2019.

Kompri. 2015. Manajemen Pendidikan. Bandung: Alfabeta

Direktorat Pembinaan Kursus dan Pelatihan (2014). Peraturan Menteri Pendidikan Nasional RI Nomor 127 Tahun 2014 tentang Standar Sarana Dan Prasarana Lembaga Kursus. (Online). (http://kemdikbud.net), diakses 24 Juli 2019.

Direktorat Pembinaan Kursus dan Pelatihan (2007). Peraturan Menteri Pendidikan Nasional RI Nomor 49 Tahun 2007 tentang Standar Pengelolaan Kursus.. Kemdikbud (Online). (http:// kursus.kemdikbud.com), diakses 24 Juli 2019.

Direktorat Pembinaan Kursus dan Pelatihan (2009). Peraturan Menteri Pendidikan Nasional Nomor 41 Tahun 2009 tentang Standar Pembimbing Kursus. Kemdikbud (Online). (http:// kursus.kemdikbud.com), diakses 23 Juli 2019.

Direktorat Pembinaan Lembaga Kursus dan Pelatihan (2008). Peraturan Presiden Nomor 12 Tahun 2008 tentang Standar Kompetensi Lulusan Tata Busana. (Online). (http://kemdikbud.com), diakses 20 Juli 2019.

Direktorat Pembinaan Lembaga Kursus dan Pelatihan (2003). Undang - Undang Republik Indonesia Nomor 20 Tahun 2003 tentang Sistem Pendidikan Nasional. (http://kemdikbud.com), diakses 20 Juli 2019. 